\title{
REKAYASA KEBUTUHAN APLIKASI MONITORING KINERJA TENAGA PENJUAL PRODUK KREDIT BANK XYZ MENGGUNAKAN MODEL SYSTEM ENGINEERING LIFE CYCLE
}

\author{
Dwi Hosanna Bangkalang ${ }^{1}$, Nina Setiyawati ${ }^{2}$ \\ ${ }^{1}$ Fakultas Teknologi dan Desain, Universitas Bunda Mulia \\ ${ }^{2}$ Fakultas Teknologi Informasi, Universitas Kristen Satya Wacana
}

\section{Article Info:}

Dikirim: 26 April 2019

Direvisi: 21 Mei 2019

Diterima: 22 Mei 2019

Tersedia Online: 29 Juni 2019

Penulis Korespondensi: Dwi Hosanna Bangkalang Fakultas Teknologi dan Desain, Universitas Bunda Mulia, Jakarta, Indonesia

Email: dwihosanna@gmail.com

\begin{abstract}
Abstrak: Peran tenaga penjual besar bagi suatu perusahaan, oleh karena itu perlu dilakukan pengawasan terhadap kinerja tenaga penjual untuk menjaga tenaga penjual bergerak di arah yang tepat sesuai dengan yang telah direncanakan sehingga dapat dipastikan tujuan perusahaan tercapai. Untuk menjalankan fungsinya dalam menarik dan mengeluarkan uang dalam masyarakat, terutama memberikan kredit dan jasa dalam lalu lintas pembayaran dan peredaran uang, Bank memiliki tenaga penjual baik untuk produk simpanan maupun kredit, dimana tenaga penjual salah satu tugasnya adalah mencari nasabah untuk menggunakan produk tersebut, sehingga membuat tenaga penjual akan banyak turun ke lapangan. Untuk mempermudah dalam pengawasan dibutuhkan aplikasi monitoring kinerja tenaga penjual. Dalam membangun suatu aplikasi, tahapan yang esensial adalah rekayasa kebutuhan karena jika dilakukan dengan kurang baik maka pembangunan aplikasi menjadi sangat rentan. Pada paper ini disajikan proses rekayasa kebutuhan aplikasi monitoring kinerja tenaga penjual berdasarkan model System Engineering Life Cycle yaitu concept development, yang terdiri dari fase needs analysis, concept exploration, and concept definition.
\end{abstract}

Kata kunci: monitoring; tenaga penjual; system engineering life cycle; concept development; produk kredit.

\begin{abstract}
The role of a salesperson for a company is big, therefore it is necessary to monitor the performance of salespeople to keep them moving in the right direction according to what has been planned in order for the company's objectives to be achieved. To carry out its function in attracting and issuing money in the community, especially providing credit and services in the traffic of payments and circulation of money, the Bank has salespeople both for savings and credit products, in which one of their duties is to find customers who would use the products. This results in a large amount of salespeople who would work in the field increasing the need of monitoring these salespeople. In developing an application, the most essential step is the engineering needs because if not done properly, application development will be very susceptible. This paper presents the process of requirements engineering of salespeople monitoring application based on the Life Cycle Engineering System model which is a concept development comprising of needs analysis, concept exploration, dan concept definition stage.
\end{abstract}

Keywords: monitoring; salespeople; life cycle engineering system; concept development; credit product. 


\section{PENDAHULUAN}

Penjualan dan hasil penjualan dianggap sebagai bagian paling penting dari keberadaan suatu perusahaan. Melihat fakta tersebut, dikatakan bahwa perusahaan tidak akan memiliki masa depan jangka panjang jika tidak ada penjualan [1]. Salah satu entitas pokok dalam proses penjualan adalah tenaga penjual, dimana tenaga penjual mengalokasikan waktu yang subtansial [2][3][4] untuk memperoleh pelanggan baru ataupun meningkatkan jumlah penjualan kepada pelanggan lama. Persepsi tenaga penjualan juga berperan penting dalam membangun customer relationship management yang kuat [5]. Tenaga penjual adalah informan kunci dalam perencanaan strategis [6], dan pelaksana kritis konsep marketing [7].

Melihat peran tenaga penjual yang besar bagi suatu perusahaan, maka perlu dilakukan pengawasan terhadap kinerja tenaga penjual untuk menjaga tenaga penjual bergerak di arah yang tepat sesuai dengan yang telah direncanakan sehingga dapat dipastikan tujuan perusahaan tercapai. Pengasawan terhadap tenaga penjual dapat dilihat dari performa penjualan yang dilakukan yang dapat diukur berdasarkan outcome (hasil penjualan) dan behavior (bagaimana mereka melakukannya). Pengukuran berdasar outcome adalah pengukuran yang dilakukan dengan melihat keuntungan, pangsa pasar, dan omset. Sedangkan pengukuran berdasarkan behavior dapat diidentifikasi dari penjualan adaptif, keterampilan komunikasi tenaga penjual, manajemen wilayah, menajemen aktivitas, kegiatan yang dilakukan tenaga penjual, serta jumlah menghubungi pelanggan [1]. Kegiatan yang dilakukan oleh tenaga penjual dan jumlah hubungan dengan pelanggan dilandasi dan mengarah pada tujuan serta sasaran perusahaan. Oleh karena itu perusahaan melakukan pengawasan terhadap performa tenaga penjual agar tujuan dan sasaran perusahaan tercapai.

Bank adalah badan usaha di bidang keuangan yang menarik dan mengeluarkan uang dalam masyarakat, terutama memberikan kredit dan jasa dalam lalu lintas pembayaran dan peredaran uang [8]. Untuk menjalankan fungsinya, Bank memiliki tenaga penjual baik untuk produk simpanan maupun kredit, dimana tenaga penjual salah satu tugasnya adalah mencari nasabah untuk menggunakan produk tersebut, sehingga membuat tenaga penjual akan banyak turun ke lapangan.

Untuk memudahkan pengawasan terhadap tenaga penjual, terutama tenaga penjual yang melakukan kegiatan utama di luar kantor, dapat dilakukan dengan menggunakan aplikasi monitoring kinerja tenaga penjual, dimana aplikasi tersebut dapat memantau dimana lokasi tenaga penjual saat jam kerja sampai berapa konsumen yang telah dikunjungi atau ditindaklanjuti.

Dalam membangun suatu aplikasi, tahapan yang esensial adalah rekayasa kebutuhan. Hal ini didasarkan pada teori bahwa pengukuran ultimatif untuk kualitas sistem adalah kemampuan sistem memenuhi kebutuhan pengguna [9] atau memenuhi tujuan yang dimaksudkan [10], dan rekayasa kebutuhan adalah fase pertama siklus hidup perangkat lunak [9] yang dilakukan proses penggalian tujuan tersebut dengan mengidentifikasi pemangku kepentingan dan kebutuhannya yang kemudian didokumentasikan dalam bentuk yang dapat dianalisis, dikomunikasikan dan diimplementasikan [10]. Rekayasa kebutuhan juga penting karena jika dilakukan dengan kurang baik maka pembangunan aplikasi menjadi sangat rentan [11].

Penelitian ini bertujuan untuk membangun aplikasi monitoring kinerja tenaga penjual produk kredit pada salah satu bank nasional di Indonesia, dimana aplikasi tersebut akan memantau lokasi tenaga penjual, jumlah serta jenis konsumen yang dijangkau tenaga penjual, serta intensitas tenaga penjual dalam menguhubungi atau menindaklanjuti konsumen sehingga menghasilkan konsumen yang menguntungkan bank. Pada paper ini disajikan proses rekayasa kebutuhan berdasarkan fase yang diusulkan oleh Kossiakoff, Sweet, Seymour, dan Biemer [12] yang dikenal dengan concept development, yang terdiri dari needs analysis, concept exploration, dan concept definition.

\section{KAJIAN PUSTAKA}

\subsection{Produk Kredit Perbankan}

Salah satu fungsi bank adalah menyalurkan dana kepada masyarakat yang membutuhkan dana. Menyalurkandana merupakan aktivitas yang sangat penting bagi bank, karena bank akan memperoleh pendapatan dari dana yang disalurkan. Penyaluran dana kepada masyarakat sebagian besar berupa [13]. Bedasarkan UU No. 10 tahun 1998 tentang perbankan, yang dimaksud dengan kredit adalah penyediaan uang atau tagihan yang dapat dipersamakan dengan itu, berdasarkan persetujuan atau kesepakatan pinjam meminjam antara bank dengan pihak lain yang mewajibkan pihak peminjam untuk melunasi utangnya setelah jangka waktu tertentu dengan pemberian bunga.

\subsection{Sistem Monitoring}

Sistem monitoring merupakan suatu proses untuk mengumpulkan data dari berbagai sumber daya. Biasanya data yang dikumpulkan merupakan data yang real time. Sistem monitoring juga memungkinkan untuk memantau dan melacak pekerjaan staf lapangan secara real time saat data sedang dikumpulkan dan memberikan akses real time ke data untuk memantau baik kualitas maupun kemajuan data tersebut [14].

\subsection{Model System Engineering Life Cycle}

Model system engineering life cycle terbagi dalam tiga tahapan utama yang saling berhubungan dan dipartisi dalam delapan fase, seperti terlihat pada Gambar 1. 


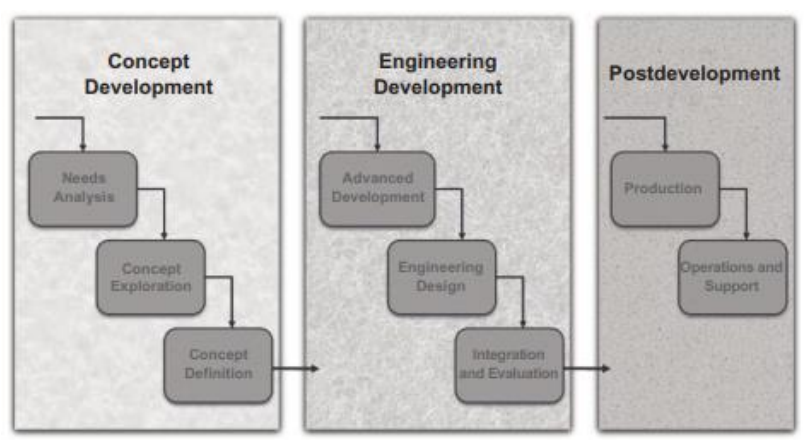

Gambar 1. Model System Engineering Life Cycle [12]

Pada Gambar 1 terlihat bahwa model system engineering life cycle terdari dari tiga tahapan besar yaitu concept development, engineering development, dan post development. Tahapan pertama, yaitu concept development adalah tahapan yang mewujudkan analisis dan perencanaan yang diperlukan untuk menetapkan kebutuhan akan sistem baru, kelayakan realisasi, dan arsitektur sistem tertentu yang dianggap terbaik memenuhi kebutuhan pengguna. Sasaran dari tahapan concept development adalah sebagai berikut: Pertama, Untuk menetapkan adanya kebutuhan yang valid untuk sistem baru yang layak secara teknis dan ekonomis. Kedua, Untuk mengeksplorasi konsep sistem yang potensial serta merumuskan dan memvalidasi seperangkat system performance requirement, Ketiga untuk memilih konsep sistem yang paling sesuai, mendefinisikan karakteristik fungsionalnya, dan mengembangkan rencana terperinci untuk tahap-tahap berikutnya dari rekayasa, produksi, dan penyebaran operasional sistem.

\section{METODOLOGI PENELITIAN}

Model system engineering life cycle terbagi dalam tiga tahapan utama yang saling berhubungan dan dipartisi dalam delapan fase [12]. Pada penelitian ini prosedur yang digunakan mengadopsi tahapan model system engineering life cycle dan berfokus pada tahapan concept development yang terdiri dari tiga fase seperti terlihat pada Gambar 2.

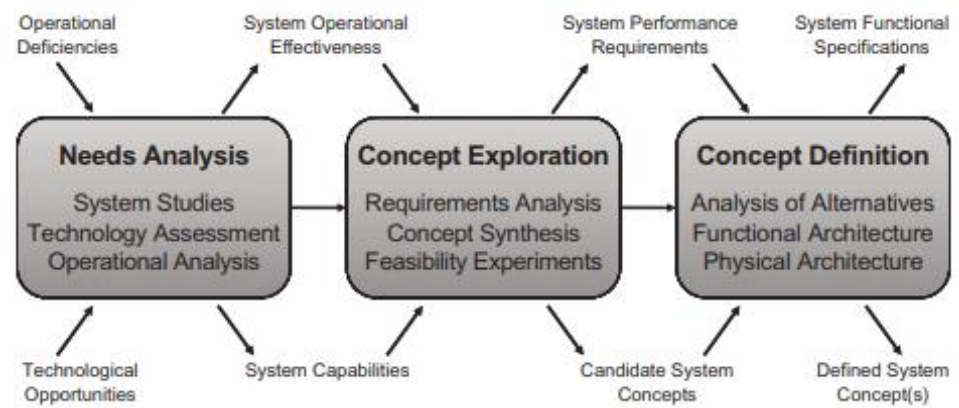

Gambar 2. Tahapan Concept Development [12]

Gambar 2 merupakan tiga fase dalam tahapan concept development, dimana proses yang dilakukan pada setiap fase dijelaskan sebagai berikut:

\subsection{Need Analysis}

Pada fase ini dilakukan pembelajaran terhadap sistem penjualan produk kredit dengan beberapa cara, seperti wawancara terhadap Kepala Divisi Kredit Bank XYZ terkait proses tenaga penjual produk kredit menjangkau calon debitur, dan mempelajari proses rekapitulasi data calon debitur. Dari hasil wawancara dan observasi, dilakukanlah analisis terhadap proses operasional penjualan produk kredit. Pada fase Needs Analysis juga dilakukan penggalian penilaian stakeholder terhadap teknologi yang dimanfaatkan dalam proses operasional penjualan produk kredit. Adapun tujuan fase Needs Analysis adalah memastikan kebutuhan operasional sebagai dasar untuk melakukan rekayasa sistem.

\subsection{Concept Exploration}

Pada fase ini dilakukan analisis kebutuhan, serta identifikasi, eksplorasi, dan sintesis konsep dengan tujuan untuk mengubah pandangan berorientasi operasional dari sistem yang diperoleh dari fase Needs Analysis menjadi pandangan berorientasi teknik yang diperlukan dalam definisi konsep dan fase pengembangan selanjutnya. 


\subsection{Concept Definition}

Pada fase ini dilakukan pemantapan terhadap alternatif-alternatif konsep yang dieksplorasi di fase Concept Exploration serta dilakukan pendefinisian kebutuhan fungsional dan karateristik fisik dari sistem yang akan dibangun. Kebutuhan ini mendefinisikan spesifikasi sistem secara teknis yang merupakan dasar masukan untuk perancangan sistem.

\section{HASIL DAN PEMBAHASAN}

\subsection{Need Analysis}

Penggalian kebutuhan operasional dilakukan pada fase ini. Dari hasil wawancara yang dilakukan, didapatkan beberapa hal. Pertama, tenaga penjual produk kredit melakukan visitasi calon debitur untuk menawarkan produk kredit Bank XYZ. Kedua, hasil visitasi ditulis manual oleh tenaga penjual, dimana akan dilakukan rekapitulasi dalam sebuah laporan berbasis excel yang nantinya dilaporkan ke Kepala Divisi Kredit Bank XYZ. Ketiga, Kepala Divisi Kredit Bank XYZ melakukan rekapitulasi data calon debitur yang telah dikumpulkan oleh semua tenaga penjual.

Dari proses yang ada terdapat beberapa kelemahan, yaitu: 1) pelaksanaan visitasi tenaga penjual tidak dapat dipantau; 2) pelaporan hasil visitasi tidak efisien dan tidak dapat langsung diterima oleh Kepala Divisi Kredit Bank XYZ; 3) rekapitulasi tidak efektif sehingga tidak secara langsung dapat memberikan informasi terkait tenaga penjual yang paling produktif maupun tenaga penjual yang tidak produktif; 4) tidak dapat diketahui secara langsung jumlah debitur untuk setiap status dan perubahannya; 5) lokasi calon debitur/debitur hanya berbasis teks sehingga kesulitan dalam memetakan debitur; 6) memungkinkan terjadinya satu debitur yang divisitasi oleh lebih dari satu tenaga penjual.

Untuk mengeksplorasi lebih jauh terkait kebutuhan terhadap aplikasi, diakukanlah wawancara terhadap Kepala Divisi Kredit Bank XYZ dan stakeholder lainnya. Berdasarkan hasil wawancara disimpulkan bahwa Bank XYZ membutuhkan aplikasi monitoring kinerja tenaga penjual yang dapat memberikan informasi secara waktu nyata terkait produktivitas tenaga penjual di lapangan, jumlah debitur dan statusnya, serta pemetaan debitur Bank XYZ. Secara garis besar, tujuan operational aplikasi yang ingin dicapai adalah: a). Meningkatkan kualitas pengawasan terhadap aktivitas tenaga penjual di lapangan untuk menjaga tenaga penjual bergerak di arah yang tepat. b). Menjamin tersedianya akses data debitur dan kinerja tenaga penjual yang cepat, waktu nyata, dan sederhana. c). Meningkatkan kualitas data debitur sebagai penunjang pengambilan keputusan yang lebih tepat sasaran untuk mencapai target rencana strategis terkait penjualan produk kredit.

\subsection{Concept Exploration}

Pada fase ini dilakukan analisis dan eksplorasi pada tujuan operasional yang didapatkan pada fase Needs Analysis dan mengubahnya menjadi kebutuhan sistem. Pada fase ini, tujuan operational dibagi menjadi 3 bagian sesuai dengan business requirement dari bank XYZ. Adapun kebutuhan sistem terlihat pada Tabel 1.

Tabel 1. Eksplorasi alternatif solusi aplikasi

\begin{tabular}{llrll}
\hline No & Tujuan Operasional & \multicolumn{1}{c}{ Kebutuhan } & \multicolumn{2}{c}{ Alternatif Solusi Aplikasi } \\
\hline 1 & Meningkatkan & kualitas & Sistem berbasis teknologi yang dapat & Membangun aplikasi berbasis \\
& pengawasan terhadap & memantau kinerja tenaga penjual & web terintegrasi yang \\
& $\begin{array}{l}\text { aktivitas tenaga penjual di } \\
\text { lapangan untuk menjaga }\end{array}$ & & menampung data kinerja pegawai \\
& tenaga penjual bergerak di & di lapangan
\end{tabular}

arah yang tepat sesuai rencana perusahaan

2 Menjamin tersedianya akses data debitur dan kinerja tenaga penjual yang cepat, waktu nyata, dan sederhana

Sistem berbasis lokasi yang dapat memantau lokasi tenaga penjual untuk memastikan tenaga penjual menjalankan tugas dan tanggung jawabnya semaksimal mungkin

Sistem akses data terpusat dan dapat diakses dari mana saja dan kapan saja

Sistem yang dapat memberikan informasi secara waktu nyata

Kepala Divisi Kredit Bank XYZ dapat menemukan dan mendapatkan data debitur dengan mudah

Kepala Divisi Kredit Bank XYZ dapat memantau perubahan status debitur
Aplikasi yang dibangun memanfaatkan Google Map

Membangun aplikasi berbasis web yang diakses melalui internet

Memberikan notifikasi masuknya beberapa data yang bersifat krusial Pengelompokan data Fungsi pencarian dengan filter berdasar atribut tertentu Tersedianya informasi perubahan status debitur pada sistem 
Jurnal SITECH, Vol 2, No 1, Juni 2019

$P$-ISSN : 2615-8531, E-ISSN : 2622-2973

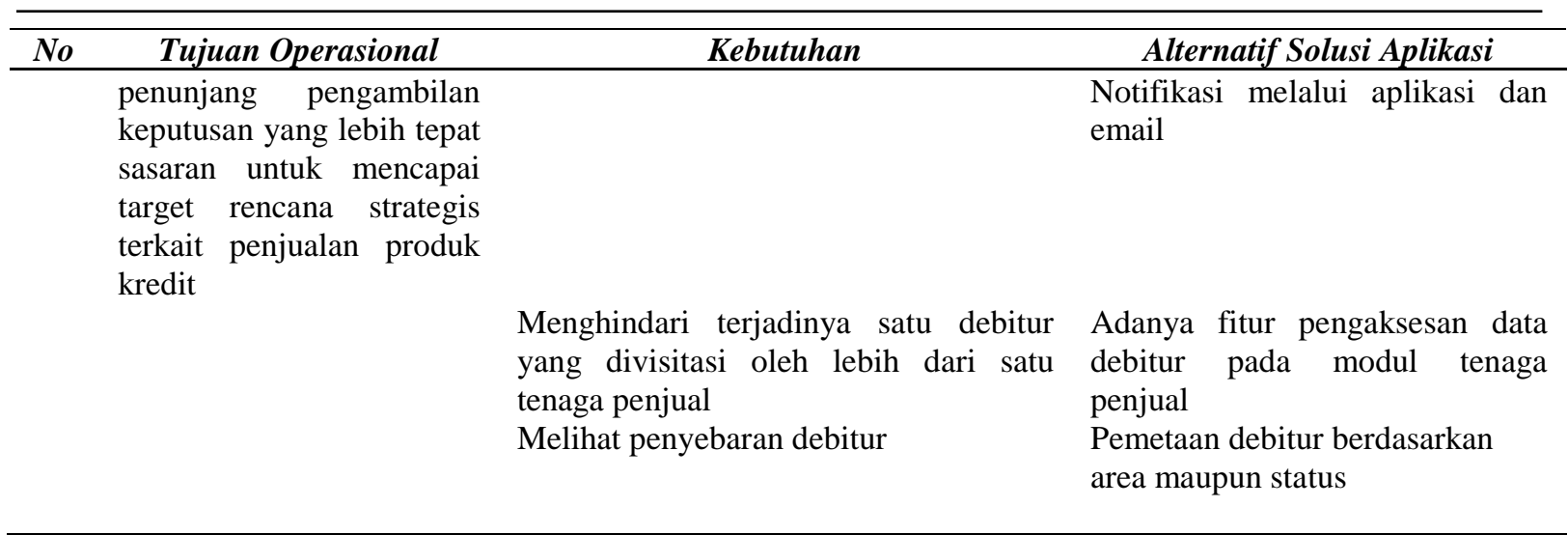

\subsection{Concept Definition}

Pada fase ini dilakukan pemilihan alternatif konsep sistem yang telah dieksplorasi pada fase sebelumnya. Dimana, berdasarkan alternatif-alternatif konsep sistem tersebut dilakukan pendefinisian kebutuhan fungsional yang memberikan spesifikasi sistem secara teknis sebagai masukan untuk tahap perancangan. Selain itu pada fase ini juga dilakukan pendefinisian karateristik fisik dari sistem yang akan dibangun. Adapun kebutuhan aplikasi monitoring kinerja tenaga penjual dan fitur yang mengakomodirnya terlihat pada Tabel 2.

Tabel 2. Kebutuhan fungsional aplikasi

\begin{tabular}{|c|c|c|}
\hline No & Kebutuhan & Fitur \\
\hline 1 & $\begin{array}{l}\text { Registrasi akun tenaga penjual dilakukan oleh } \\
\text { Administrator }\end{array}$ & Registrasi dan autentikasi pengguna \\
\hline 2 & Pengguna dapat mengubah password & \\
\hline 3 & Administrator dapat melakukan pengelolaan akun & \\
\hline 4 & $\begin{array}{l}\text { Terdapat beberapa hak akses yaitu Kepala Divisi Kredit } \\
\text { Pusat, Kepala Divisi Kredit Cabang, Tenaga Penjual }\end{array}$ & \\
\hline 1 & $\begin{array}{l}\text { Tenaga penjual dapat melaporkan aktivitas visitasi terhadap } \\
\text { debitur secara waktu nyata }\end{array}$ & $\begin{array}{l}\text { Pelaporan aktivitas tenaga penjual } \\
\text { dan data debitur }\end{array}$ \\
\hline 2 & $\begin{array}{l}\text { Tenaga penjual melakukan input data debitur beserta } \\
\text { statusnya dan lokasi debitur }\end{array}$ & \\
\hline 3 & Tenaga penjual melaporkan lokasi dirinya & \\
\hline 4 & $\begin{array}{l}\text { Tenaga penjual dapat melakukan status debitur di } \\
\text { kunjungan berikutnya }\end{array}$ & \\
\hline 5 & $\begin{array}{l}\text { Aplikasi memberikan notifikasi kepada tenaga penjual jika } \\
\text { debitur yang dikunjunginya adalah tanggung jawab dari } \\
\text { tenaga penjual yang lain }\end{array}$ & \\
\hline 6 & $\begin{array}{l}\text { Aplikasi memberikan proteksi radius lokasi yang diijinkan } \\
\text { untuk memasukkan data debitur }\end{array}$ & \\
\hline 1 & $\begin{array}{l}\text { Aplikasi memberikan notifikasi terhadap beberapa data } \\
\text { krusial yang dimasukkan oleh tenaga penjual kepada } \\
\text { Kepala Divisi Kredit }\end{array}$ & $\begin{array}{l}\text { Monitoring aktivitas tenaga penjual } \\
\text { dan data debitur }\end{array}$ \\
\hline 2 & $\begin{array}{l}\text { Aplikasi memberikan notifikasi rekap data aktivitas pada } \\
\text { hari tersebut kepada Kepala Divisi Kredit }\end{array}$ & \\
\hline 3 & $\begin{array}{l}\text { Aplikasi menyediakan katalog data untuk melihat daftar } \\
\text { data yang tersedia terkait debitur }\end{array}$ & \\
\hline 1 & Aplikasi menyediakan informasi spasial debitur & $\begin{array}{l}\text { Pemetaan data debitur berbasis } \\
\text { Google Map }\end{array}$ \\
\hline 2 & $\begin{array}{l}\text { Aplikasi menyediakan pemetaan data debitur dengan filter } \\
\text { berdasarkan area maupun status }\end{array}$ & \\
\hline
\end{tabular}

Tabel 2 merupakan daftar kebutuhan fungsional aplikasi dimana kebutuhan dikelompokkan berdasarkan fitur yang akan mengakomodir nantinya. Daftar kebutuhan sistem dibagi ke dalam 4 modul utama. Modul registrasi, modul laporan aktivitas tenaga penjual dan data debitur, modul monitoring aktivitas dan pemetaan data debitur berbasis google map. Ke 4 modul ini terintegrasi dalam sebuah aplikasi dengan arsitektur sistem seperti pada gambar 3 . 


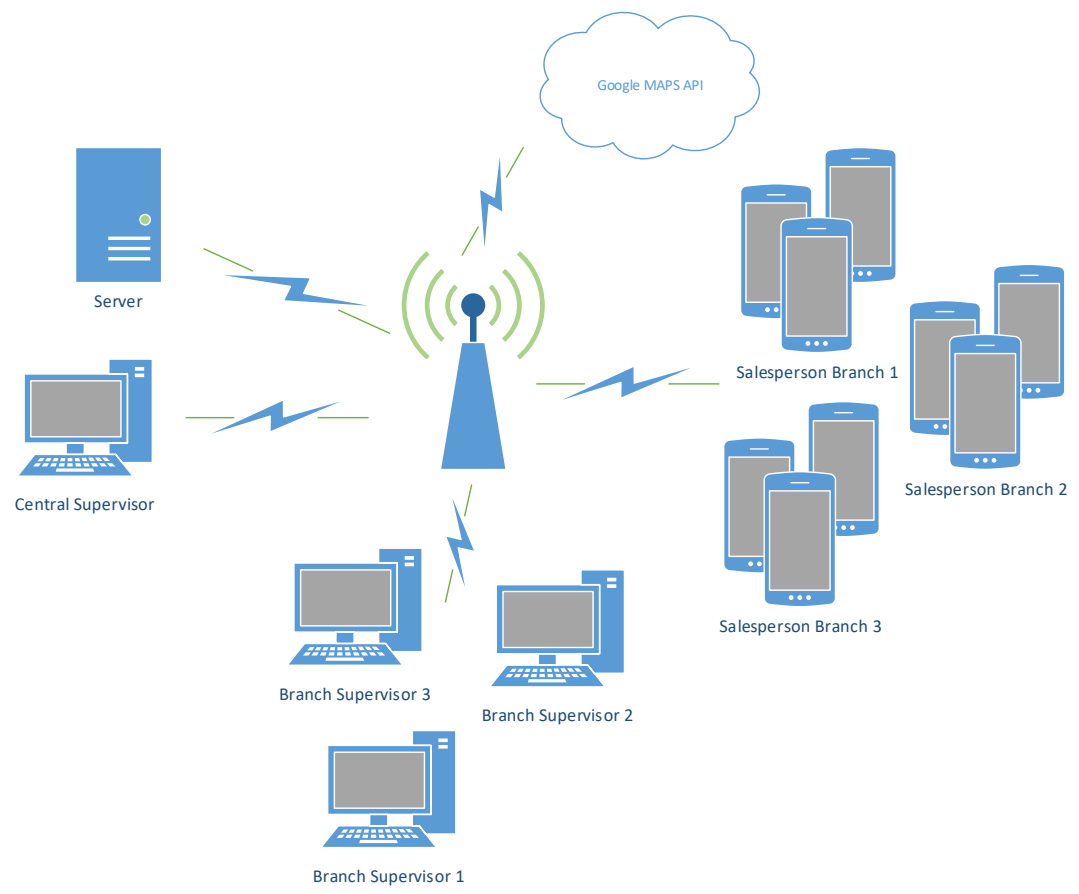

Gambar 3. Arsitektur Sistem

Gambar 3 merupakan arsitektur sistem yang akan dibangun. Terdapat 4 komponen utama yaitu jaringan, server, komputer user dan mobile untuk tenaga penjual. Sistem terintegrasi dibangun agar monitoring dan pertukaran data dapat terjadi secara waktu nyata dan cepat. Tiap komponen saling berinteraksi dengan koneksi internet. Pada komputer user, supervisor tiap cabang dan supervisor pusat dapat memantau secara real time kinerja tenaga penjual melalui dashboard yang disediakan. Pada aplikasi mobile, tenaga penjual dapat menginputkan data debitur baik yang potential, prospek maupun nasabah tetap. Selanjutnya, gambar 4 merupakan use case diagram sistem yang akan dibangun. Terdapat 4 aktor yang dapat menggunakan aplikasi ini yaitu Administrator untuk mengelola master data, Supervisor Cabang untuk monitoring kinerja dan pemetaan nasabah, Supervisor Pusat untuk monitoring tiap cabang dan pemetaan nasabah tiap cabang, dan tenaga penjual untuk menambahkan data dan lokasi debitur.

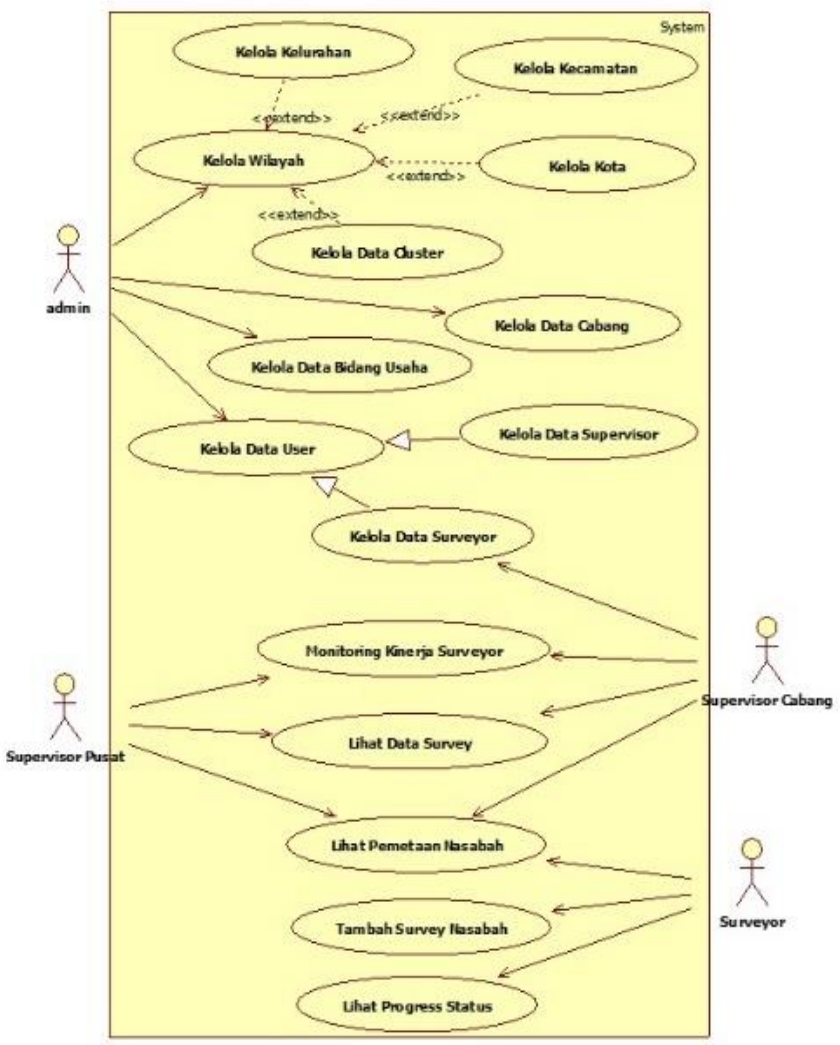

Gambar 4. Use Case Diagram 
Gambar 5 merupakan adalah functional flow diagram untuk sistem yang akan dibangun. Diagram ini menggambarkan alur fungsional sistem sesuai dengan kebutuhan dari bank XYZ.

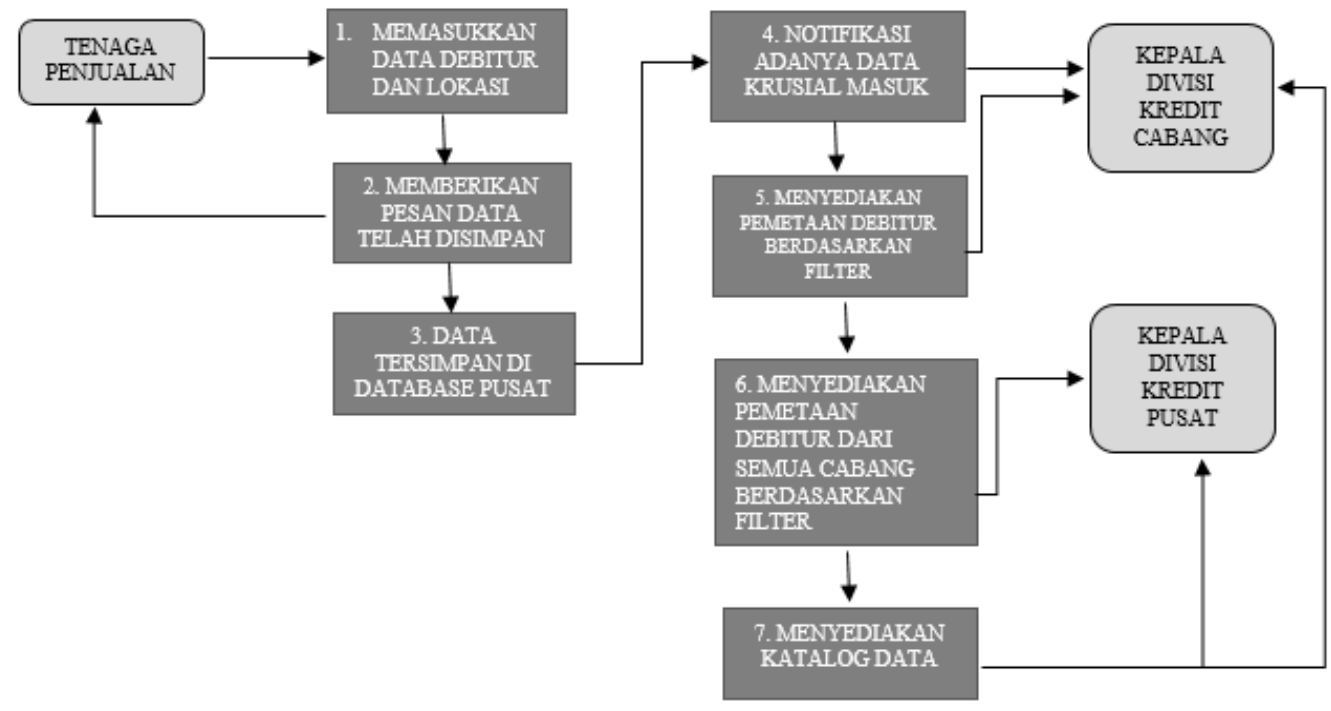

Gambar 5. Functional Flow Diagram

Terlihat pada functional flow diagram dimulai dari tenaga penjualan: 1) Tenaga penjual harus memasukan data debitur dan lokasi debitur. Untuk meningkatkan keamanan, tenaga penjual juga diminta wajib menginputkan lokasinya saat penginputan data debitur sehingga mengurangi kecurangan tenaga penjual. 2) Sistem akan memberikan pemberitahuan jika data telah tersimpan. 3) Data yang diinputkan akan tersimpan di database pusat. 4) Sistem akan memberikan pemberitahuan kepada supervisor cabang maupun pusat jika terdapat data debitur baru ataupun update data debitur. 5) Sistem memberikan fungsional untuk supervisor cabang bisa memetakan data debitur. 6) Sistem memberikan fungsional untuk supervisor pusat bisa memetakan data debitur menurut data cabang. 7) Sistem menyediakan laporan kinerja untuk seluruh tenaga penjual maupun data debitur.

\section{KESIMPULAN}

Berdasarkan rekayasa kebutuhan yang telah dilakukan, disimpulkan bahwa Bank XYZ membutuhkan aplikasi monitoring kinerja tenaga penjual dimana aplikasi tersebut memerlukan servis berbasis lokasi sehingga dibutuhkan penerapan teknologi Google Map. Kebutuhan mendesak dalam pemantauan kinerja tenaga penjual adalah pertukaran data secara waktu nyata, sehingga aplikasi harus dibangun berbasis web dengan data terpusat dan terintegrasi sehingga bank pusat dapat memantau aktivitas di tiap cabang dengan dashboard summary data debitur dan tiap cabang dapat memantau kinerja tenaga penjual. Sistem akan memberikan notifikasi pada beberapa aktivitas data yang krusial, sehingga supervisor dapat selalu mengetahui aktivitas tenaga penjual dan debitur. Pada penelitian selanjutnya, akan dibangun aplikasi monitoring kinerja tenaga penjual sesuai dengan rekayasa kebutuhan yang telah dilakukan pada penelitian ini.

\section{DAFTAR PUSTAKA}

[1] J. Wahlberg-Järvenkylä, "The Impact of Sales Performance Measurement in Day-to-Day Sales Work," Master's Thesis, International Business Management, Yrkeshögskolan Arcada, 2017.

[2] H. Sujan, B.A. Weitz, \& N. Kumar," Learning orientation, working smart, and effective selling," Journal of Marketing, vol 58, pp 39-52, 1994.

[3] D. Rangajaran, E. Jones, \& W. Chin,"Impact of sales force automation on technology related stress, effort, and technology usage among salespeople," Industrial Marketing Management, vol 34, pp 345-354, 2005.

[4] P. H. Donassolo, \& C. A. de Matos, "The predictors of sales performance: a study with wholesale sellers,"Review of Business Management, vol. 16, pp 448-465, 2014.

[5] R. R. Mullins, M. Ahearne, S. K. Lam, Z. R. Hall,\& J. P. Boichuk, "Know Your Customer: How Salesperson Perceptions of Customer Relationship Quality Form and Influence Account Profitability", Journal of Marketing, vol 78, pp 38-58, 2014.

[6] A. Sharma, \& D. M. Lambert, "How Accurate Are Salespersons' Perceptions of Their Customers?," Industrial Marketing Management, vol 23, pp 357-365, 1994.

[7] D. E. Hughes, \& Michael Ahearne, "Energizing the Reseller's Sales Force: The Power of Brand Identification," Journal of Marketing, vol 74, pp 81-96, 2010. 
[8] Badan Pengembangan dan Pembinaan Bahasa, Kamus Besar Bahasa Indonesia, Kementerian Pendidikan dan Kebudayaan Republik Indonesia, https://kbbi.kemdikbud.go.id/, 2016, retrieved March 13, 2019.

[9] K. Pohl, "Requirement engineering: An overview," Encyclopedia of Computer Science and Technology, vol 36, 1996.

[10] Bashar Nuseibeh Steve Easterbrook, "Requirements Engineering: A Roadmap" In Proceedings of the 22nd International Conference on on Software Engineering, ICSE 2000, 2000.

[11] SWEBOK, Guide to the Software Engineering Body of Knowledge, IEEE Computer Society, 2001.

[12] A. Kossiakoff, W. N. Sweet, S. J. Seymour, \& S. M. Biemer, Systems Engineering Principles and Practice, 2nd ed., John Wiley \& Sons, Inc., New Jersey, 2011.

[13] Ismail 2011, Akuntansi Bank: Teori dan Aplikasi dalam Rupiah, Edisi Pertama, Cetakan Kedua, Kencana, Jakarta.

[14] Thakkar, M. dkk. 2013. "Mobile-based Technology for Monitoring \& Evaluation. 